JUSTYNA ZAJĄC

Uniwersytet Warszawski

DOI : $10.14746 /$ rie.2017.11.18

\title{
Unia Europejska wobec konfliktu izraelsko-palestyńskiego w latach 2009-2017
}

Kto nie idzie do przodu ten się cofa. Johann Wolfgang von Goethe

\section{Wstęp}

Przez kilka ostatnich dekad Wspólnota/Unia Europejska była jednym z najważniejszych podmiotów działających na rzecz rozwiązania konfliktu izraelsko-palestyńskiego. Jednak w XXI wieku rola Unii Europejskiej w rozwiązywaniu tego jednego z najdłużej trwających konfliktów międzynarodowych maleje. Problemy wewnętrzne, z jakimi Unia Europejska i jej państwa członkowskie borykają się od kilku lat, Brexit, destabilizacja obszaru Afryki Północnej i Bliskiego Wschodu, kryzys ukraiński, zmieniający się układ sił w świecie - to najważniejsze determinanty obecnej polityki UE wobec konfliktu izraelsko-palestyńskiego.

Jakie stanowisko Unia Europejska zajmuje wobec konfliktu izraelsko-palestyńskiego wraz z dynamicznie zmieniającymi się uwarunkowaniami wewnętrznymi i międzynarodowymi? Jakie podejmuje działania? Czy stosowane przez UE środki i metody są kontynuacją tych stosowanych już wcześniej? Czy Unia Europejska jest nadal liczącym się aktorem w rozwiązywaniu konfliktu izraelsko-palestyńskiego? Pytania te stanowią trzon rozważań w niniejszym artykule.

Analizą zostanie objęty okres 2009-2017. Rok 2009 jako data początkowa analizy został wybrany z kilku powodów. Po pierwsze, kryzys finansowy i ekonomiczny w Unii Europejskiej dał wówczas o sobie wyraźnie znać, a gospodarka europejska stanęła w obliczu największego, od lat 30 . XX wieku, kryzysu. Po drugie, 1 grudnia 2009 r. wszedł w życie traktat lizboński, który wprowadził nowe regulacje, w tym w zakresie wspólnej polityki zagranicznej, bezpieczeństwa i obrony. Po trzecie, w okresie 2009-2017 konflikt izraelsko-palestyński eskalował. W latach 2008-2017 Izrael podjął trzy operacje zbrojne w Strefie Gazy: „Płynny Ołów” (2008/09), „Filar Obrony” (2012) oraz „Ochronny Brzeg” (2014). Po czwarte, administracja Baracka Obamy, który objął urząd prezydenta USA w styczniu 2009 r. rozpoczęła działania na rzecz rewitalizacji palestyńsko-izraelskich rozmów pokojowych.

Teza artykułu zawiera się w zdaniu, iż w okresie 2009-2017 Unia Europejska zasadniczo kontynuowała swoją dotychczasową politykę wobec konfliktu izraelsko-palestyńskiego, jednak w obliczu dynamicznie zmieniających się uwarunkowań wewnętrznych i międzynarodowych, polityka ta staje coraz mniej efektywna, a rola Unii Europejskiej w rozwiązywaniu konfliktu izraelsko-palestyńskiego, na tle innych aktorów, maleje. 


\section{Zmiana uwarunkowań polityki UE wobec konfliktu izraelsko-palestyńskiego}

W latach 2009-2017 nastapiła zasadnicza zmiana uwarunkowań polityki Unii Europejskiej wobec konfliktu izraelsko-palestyńskiego, zarówno o charakterze wewnętrznym, jak i międzynarodowym. 1 grudnia 2009 r. wszedł w życie traktat lizboński, który wśród różnych zmian i modyfikacji, dawał Unii Europejskiej również nowe możliwości działania w zakresie wspólnej polityki zagranicznej, bezpieczeństwa i obrony, bowiem na mocy traktatu utworzono nowe instytucje - przewodniczącego Rady Europejskiej, Wysokiego przedstawiciela Unii ds. zagranicznych i polityki bezpieczeństwa oraz Europejską Służbę Działań Zewnętrznych. Stworzyło to większą spójność w polityce zewnętrznej Unii Europejskiej, upraszczając jej strukturę. Przewodniczący Rady Europejskiej wybierany na dwa i pół roku, z możliwością jednokrotnego przedłużenia mandatu organizuje prace Rady Europejskiej i wspomaga osiąganie spójności i konsensusu w Radzie Europejskiej. Wysoki Przedstawiciel Unii ds. spraw zagranicznych i polityki bezpieczeństwa połączył kompetencje dwóch wcześniejszych funkcji: Wysokiego Przedstawiciela ds. WPiZB i komisarza ds. stosunków zewnętrznych, dzięki temu zlikwidowano podwójną, nieprzejrzystą strukturę urzędów do spraw polityk zewnętrznych UE $\mathrm{U}^{1}$. Zgodnie z traktatem lizbońskim Wysoki Przedstawiciel pełni również funkcję wiceprzewodniczącego Komisji Europejskiej, stąd też w skrócie przyjęło się określać tę funkcję jako HR/VP (High Representative of the Union for Foreign Affairs and Security Policy/Vice-President of the European Commission). HR/VP przewodniczy także Radzie do Spraw Zagranicznych, dzięki czemu wyeliminowano dotychczasową konkurencję między tymi urzędami. Wysokiego Przedstawiciela wpiera ESDZ, będąca swoistym rodzajem służby dyplomatycznej UE, składająca się z urzędników właściwych służb Sekretariatu Generalnego Rady i Komisji, jak również z personelu delegowanego przez krajowe służby dyplomatyczne. Przez wielu ustalenia te zostały zinterpretowane jako kolejny krok w stronę pogłębiania integracji europejskiej (Koehler, 2010). Jednakowoż traktat z Lizbony umocnił międzyrządowy charakter polityki zagranicznej, bezpieczeństwa i obrony Unii Europejskiej, co uzależniło ją nadal od woli politycznej państw członkowskich (Zając, 2011a; Zięba, 2014).

Wejście w życie traktatu lizbońskiego zbiegło się w czasie z postępującym kryzysem finansowym, w jakim pogrążał się Zachód od kilkunastu miesięcy. W efekcie, Unia Europejska znalazła się w największym, od lat 30. XX wieku kryzysie ekonomicznym, który rozlał się na inne sfery jej funkcjonowania (Zięba, 2011a; Stolarczyk, 2012; Czachór, 2013; Grosse, 2016). W części państw unijnych wzmocniły się tendencje do renacjonalizacji polityk, a w Wielkiej Brytanii doszło do zakwestionowania samej idei integracji europejskiej. W czerwcu 2016 r. niemal 52\% społeczeństwa brytyjskiego zadecydowała w referendum o opuszczeniu przez Wielką Brytanię UE, co rozpoczęło proces Brexit. Wychodzenie z Unii Europejskiej jednego z największych i najsilniejszych jej członków stawia przed UE poważne wyzwanie, co do dalszego jej

${ }^{1}$ W konsekwencji Wysoki Przedstawiciel wchłonął funkcję tzw. trójki, w skład której, zgodnie z traktatem amsterdamskim, wchodził reprezentant Prezydencji UE (szef rządu lub minister spraw zagranicznych), Wysoki Przedstawiciel ds. WPZiB i komisarz ds. stosunków zewnętrznych (lub nawet sam przewodniczący Komisji Europejskiej). 
funkcjonowania. W innych państwach członkowskich wzrastają tendencje ksenofobiczne i nacjonalistyczne, a także eurosceptyczne.

Niewątpliwie na tendencje te wpływ mają uwarunkowania zewnętrzne, które generują rosnące wyzwania i zagrożenia dla bezpieczeństwa Unii Europejskiej, jej państw członkowskich oraz ich społeczeństw. Zapoczątkowana społecznymi ruchami w Tunezji w grudniu 2010 r. Arabska Wiosna rozlała się na inne państwa Afryki Północnej i Bliskiego Wschodu niczym efekt domina. W efekcie kumulacji różnych czynników, obszar ten stał się areną eskalujących konfliktów i kryzysów, których negatywne konsekwencje dotykają również Unię Europejską. Rosnącymi problemami stają się fale uchodźców i nielegalnych imigracji oraz coraz częstsze zamachy terrorystyczne na obszarze państw unijnych, organizowane przez radykalnych islamistów, powiązanych bądź sympatyzujących z ISIL.

W oku bliskowschodniego cyklonu doszło do eskalacji konfliktu izraelsko-palestyńskiego. Kiedy po serii porozumień pokojowych między Izraelem a Autonomią Palestyńską, Jordanią i Libanem osiągniętych w dekadzie lat 90. XX wieku, we wrześniu 2000 toku wybuchło palestyńskie powstanie przeciwko Izraelowi - Intifada II - proces pokojowy izraelsko-palestyński, podobnie jak cały proces izraelskoarabski, załamał się. Podejmowane przez różnych aktorów międzynarodowych próby skłonienia stron konfliktu do dalszych rokowań zakończyły się niepowodzeniem. Ani Arabska Inicjatywa Pokojowa (28 marca 2002 r.), ani „Mapa Drogowa” ogłoszona przez Kwartet Bliskowschodni - ONZ, UE, USA, Rosję (30 kwietnia 2003 r.), ani międzynarodowa konferencja w Annapolis w listopadzie 2007 r. nie zdołały poprawić klimatu w relacjach izraelsko-palestyńskich. Sytuacja pogorszyła się, kiedy w styczniu 2006 r. wybory parlamentarne w Autonomii Palestyńskiej wygrał Hamas, pokonując Al. Fatah. W efekcie, w Autonomii Palestyńskiej nastapił kryzys polityczny, a między zwolennikami bardziej radykalnego Hamasu i bardziej umiarkowanego w swoim programie Al. Fatahu doszło do bratobójczych walk. W czerwcu 2007 r. utworzono rząd jedności narodowej, co jednak nie uspokoiło sytuacji. W konsekwencji dalszych walk Hamas objął władzę w Strefie Gazy, a Al. Fatah na Zachodnim Brzegu Jordanu. Napięcia między Izraelem a Hamasem znacznie się nasiliły i coraz częściej dochodziło do konfrontacji. W listopadzie 2008 r. podczas działań izraelskich niszczenia tuneli podziemnych łączących Strefę Gazy z Egiptem zginęło sześciu bojowników Hamasu, na co organizacja ta odpowiedziała ostrzałami i atakami rakietowymi na terytorium Izraela. Działania te z kolei pociągnęły za sobą zmasowany atak sił izraelskich (IDF) na Strefę Gazy. Operacja pod kryptonimem „Płynny Ołów” (Operation Cast Lead) rozpoczęła się 27 grudnia 2008 r. i miała na celu zniszczenie struktury Hamasu i zlikwidowanie jej przywódców (the „Guardian”, 2009). Trwająca 22 dni ofensywa charakteryzowała się dużym stopniem przemocy. Powołana przez ONZ Misja Śledcza, w tzw. raporcie Goldstone’’a oskarżyła Izrael i palestyńskie grupy zbrojne o popełnienie zbrodni wojennych i możliwość dopuszczenia się zbrodni przeciwko ludzkości. Straty po obydwu stronach były jednak nieporównywalne; operacja kosztowała życie ponad 1400 Palestyńczyków, przy izraelskich stratach liczących kilka osób.

W obliczu eskalacji konfliktu izraelsko-palestyńskiego, zwłaszcza na linii IzraelHamas w styczniu 2009 r. nowo wybrany prezydent USA - Barack Obama podjął dzia- 
łania na rzecz rewitalizacji rozmów pokojowych i powołał Specjalnego wysłannika ds. procesu pokojowego - doświadczonego polityka partii demokratycznej, George'a Mitchella. Po nieudanych próbach nakłonienia stron konfliktu do bezpośrednich rozmów, w maju 2011 r. Mitchell zrezygnował jednak z pełnionej funkcji. Kilka miesięcy później, we wrześniu 2011 r. prezydent Autonomii Palestyńskiej Mahmud Abbas złożył do Sekretarza Generalnego Organizacji Narodów Zjednoczonych Ban Ki-Moona wniosek o przyjęcie Palestyny w poczet członków tej organizacji, jako państwa istniejącego w granicach z 4 czerwca 1967 r., ze stolicą w Jerozolimie. Izraelski premier Benjamin Netanjahu określił działania Abbasa teatrem absurdu (Lyon, Mohammed, 2011), jednak, głosowany na forum Zgromadzenia Ogólnego NZ 29 listopada 2012 r., wniosek zyskał poparcie większości. Za przyznaniem Palestynie statusu „nieczłonkowskiego państwa obserwatora" opowiedziało się 138 państw, przy 9 przeciwnych i 41 wstrzymujących. Wcześniej, na początku listopada 2012 r. doszło ponownie do eskalacji konfliktu. W trwającej tydzień (14-21 listopada 2012 r.) operacji sił izraelskich pod kryptonimem „Filar Obrony” (Operation Pillar of Defence), prowadzonej w Strefie Gazy, zgodnie z danymi ONZ zostało zabitych 174 Palestyńczyków, z czego przynajmniej 168 poniosło śmierć w militarnej akcji izraelskiej, w tym 33 dzieci i 13 kobiet. Straty Izraela wyniosły 6 osób, w tym czterech cywilów. W marcu 2013 r. prezydent Barack Obama wezwał strony konfliktu do bezwarunkowych negocjacji. W efekcie, w sierpniu tego roku rozpoczęły się bezpośrednie rozmowy, które, zgodnie z założeniem, miały trwać dziewięć miesięcy. Nie udało się jednak osiagnać porozumienia. W kwietniu 2014 r. negocjacje załamały się. 8 lipca 2014 r., w obliczu fiaska rozmów, po porwaniu i zabójstwie przez członków Hamasu trzech izraelskich nastolatków, porwaniu i zamordowaniu w odwecie przez izraelskich ekstremistów palestyńskiego nastolatka, brutalnych starciach między Palestyńczykami a Izraelczykami, szczególnie we wschodniej Jerozolimie, atakach rakietowych Hamasu na miasta Izraela, siły izraelskie (IDF) rozpoczęły kolejną ofensywę w Strefie Gazy. Atak pod kryptonimem „Ochronny Brzeg” (Operation Protective Edge) trwała do 26 sierpnia. Śmierć poniosło w niej ponad 2100 Palestyńczyków oraz 72 Izraelczyków. Do kolejnej fali przemocy doszło we wrześniu 2015 r., kiedy rozpoczęły się ataki nożowników na Izraelczyków na tle sporu o dostęp Palestyńczyków do obiektów sakralnych na Wzgórzu Świątynnym w Jerozolimie, które zarówno żydzi, jak i muzułmanie uznają za swoje miejsce kultu religijnego. Liczne ataki trwające przez kilka miesięcy przyniosły śmierć ponad 40 Izraelczyków (w atakach palestyńskich) i 250 Palestyńczyków (w interwencjach izraelskich sił bezpieczeństwa).

Również we wschodnim sąsiedztwie Unii Europejskiej sytuacja stała się silnie zdestabilizowana. Wraz z kryzysem ukraińskim i po aneksji Krymu przez Rosję w marcu 2014 r. doszło do zaostrzenia relacji rosyjsko-unijnych i wzrostu napięć między Zachodem (UE i USA) a Rosją. Sytuacja na Ukrainie pozostaje mocno niestabilna, a polityka Rosji wpisuje się w szerszą tendencję zmian w globalnym układzie sił, w której rośnie międzynarodowa rola Chin oraz Rosji, a rola Unii Europejskiej i jej państw członkowskich maleje. Pod znakiem zapytania stoi także rozwój stosunków amerykańsko-unijnych. Po amerykańskich wyborach prezydenckich 2016 r., w których zwycięstwo odniósł Donald Trump przyszłość relacji europejsko-amerykańskich, podobnie jak cała polityka zagraniczna USA, wciąż pozostają niewiadomą. 


\section{Stanowisko UE wobec konfliktu izraelsko-palestyńskiego w latach 2009-2017: kontynuacja czy zmiana?}

Stanowisko Unii Europejskiej wobec konfliktu izraelsko-palestyńskiego w latach 2009-2017 było kontynuacją jej wcześniejszej polityki, której podwaliny zostały określone w kilku kluczowych dokumentach: deklaracji weneckiej (13 czerwca 1980 r.), deklaracji berlińskiej (25 marca 1999 r.), deklaracji sewilskiej (22 czerwca 2002 r.), jak również w „Strategii działania na rzecz bliskowschodniego procesu pokojowego”, przedstawionej przez Wysokiego Przedstawiciela ds. WPZiB - Javiera Solanę oraz Komisarza ds. Stosunków Zewnętrznych i Polityki Sąsiedztwa - Benitę Ferrero-Waldner, w listopadzie $2007 \mathrm{r}$.

Unia Europejska niezmiennie popiera ideę rozwiązania konfliktu izraelsko-palestyńskiego w oparciu o zasadę utworzenia dwóch państw (two-state solution) - Izraela i Palestyny. Zgodnie ze stanowiskiem UE terytoria okupowane przez Izrael od wojny sześciodniowej 1967 r. obejmują Wzgórza Golan, Strefę Gazy i Zachodni Brzeg oraz Wschodnią Jerozolimę. Izrael, winien wycofać się z tych ziem, z niewielkimi modyfikacjami, jeśli są one niezbędne, które jednak muszą być zgodne z rezolucjami Rady Bezpieczeństwa ONZ nr 242, 338, 1397, 1402 i 1515 oraz poszanowaniem reguł przyjętych w bliskowschodnim procesie pokojowym, rozpoczętym jesienią 1991 r. Konferencją Madrycką. Zasada ta została wyartykułowana przez Wspólnotę Europejską już w deklaracji weneckiej 1980 r., w której zapisano, że naród palestyński (Palestinian people) musi mieć przyznaną możliwość ,,pełnego zrealizowania swojego prawa do samostanowienia", a OWP powinna być włączona do rokowań pokojowych. Było to de facto opowiedzeniem się za prawem Palestyńczyków do posiadania własnego państwa. Stanowisko to pociaga za sobą głoszony przez Unię Europejską pogląd, iż budowa przez Izrael osiedli żydowskich na okupowanych Terytoriach Palestyńskich - Zachodnim Brzegu Jordanu i we Wschodniej Jerozolimie jest nielegalna z punktu widzenia prawa międzynarodowego, stanowi poważną przeszkodę dla pokoju i wdrożenia koncepcji dwóch państw. Jednocześnie Unia Europejska potępia wszelkie akty przemocy, ponieważ hamują one postęp w procesie pokojowym, uznaje prawo Państwa Izrael do podejmowania działań służących ochronie jego obywateli, jednak wyraźnie podkreśla, iż muszą być one zgodne z prawem międzynarodowym. Palestyńczycy natomiast, zgodnie ze stanowiskiem UE powinni cieszyć się poszanowaniem przez Izrael prawa do suwerenności i takich warunków, które będą oznaczać koniec okupacji. W spornej sprawie statusu Jerozolimy Unia Europejska nie opowiada się za przynależnością tego miasta do żadnej ze stron, jednak wyraźnie podkreśla, że nie uzna żadnych zmian terytorialnych po 4 czerwca 1967 r., włączając w to Jerozolimę, dopóki zmiany takowe nie zostaną zatwierdzone przez strony konfliktu. Z tego też powodu UE nie uznała i skrytykowała decyzję prezydenta Donald Trumpa z 6 grudnia 2017 r. o przeniesieniu ambasady USA z Tel Awiwu do Jerozolimy i tym samym uznaniu tego miasta za stolicę Izraela. Unia Europejska nie proponuje także żadnych rozwiązań w kwestii uchodźców palestyńskich. Popiera sprawiedliwe i możliwe do wykonania rozwiązanie tej kwestii i deklaruje, że będzie szanować porozumienie zawarte przez stronę izraelską i palestyńską. Podkreśla jednocześnie, iż od 1971 r. udziela dużego wsparcia uchodźcom palestyńskim poprzez Agencję ONZ ds. Pomocy Uchodźcom 
Palestyńskim - UNRWA. Jednocześnie Unia Europejska, spośród aktorów międzynarodowych, od kilku dekad ma największy wkład w budowę państwa palestyńskiego, uznając iż tylko niepodległe, demokratyczne i zdolne do funkcjonowania państwo palestyńskie zapewni Izraelowi bezpieczne sąsiedztwo.

Niezmiennie także Unia Europejska deklaruje współpracę z innymi podmiotami - państwowymi i niepaństwowymi - w rozwiązaniu konfliktu izraelsko-palestyńskiego. Najważniejszym parterem w tym względzie są Stany Zjednoczone, które w okresie pozimnowojennym odgrywały najważniejszą rolę dyplomatyczną w rozwiązywaniu konfliktu arabsko-izraelskiego. Każda inicjatywa pokojowa administracji amerykańskich na przełomie XX/XXI była popierana przez Unię Europejską: konferencja pokojowa w Annapolis w 2007 r., jak również wysiłki mediacyjne administracji Baracka Obamy, podejmowane od stycznia 2009 r. W Globalnej Strategii na rzecz Polityki Zagranicznej i Bezpieczeństwa Unii Europejskiej, przyjętej w czerwcu 2016 r. stwierdza się, że w kwestii konfliktu palestyńsko-izraelskiego UE będzie ściśle współpracować z kwartetem bliskowschodnim, Ligą Państw Arabskich i wszystkimi kluczowymi zainteresowanymi stronami, by utrzymać perspektywę wprowadzenia trwałego rozwiązania na zasadach two-state solution w oparciu o granice z 1967 r. oraz by przywrócić warunki umożliwiające prowadzenie konstruktywnych negocjacji pokojowych. Większą rolę UE odgrywa w sferze ekonomicznej i finansowej. Unia Europejska wraz z USA patronuje międzynarodowemu komitetowi (Ad Hoc Liaison Committee - AHLC), powołanemu w 1993 r. w celu udzielenia pomocy rozwojowej, w tym pomocy finansowej Palestyńczykom. Komitet ten, któremu przewodniczy Norwegia skupia 15 państw. W 2002 r. Unia Europejska została także członkiem Kwartetu Bliskowschodniego obok Stanów Zjednoczonych, ONZ i Rosji. Wraz z silną destabilizacją Bliskiego Wschodu w ostatniej dekadzie i narastającej rywalizacji o wpływy między USA a Rosją trudno jest jednak o efektywne działanie tej instytucji (Tocci, 2011).

Pomimo utrzymywania przez Unię Europejską dotychczasowej linii polityki wobec konfliktu izraelsko-palestyńskiego kluczowe znaczenie ma jednak fakt, iż w obliczu nowych wyzwań i zagrożeń narastających wraz z problemami wewnętrznymi UE oraz destabilizacją Afryki Północnej, Bliskiego Wschodu i Europy Wschodniej - konflikt ten został w polityce unijnej, zepchnięty na dalszy plan. Ustapił on miejsca m.in. problemowi napływających do Europy uchodźców i nielegalnych emigrantów, zamachom terrorystycznym i zagrożeniom związanym z rewizjonistyczną polityką Rosji. W efekcie, w Globalnej Strategii na rzecz Polityki Zagranicznej i Bezpieczeństwa Unii Europejskiej, przyjętej w czerwcu 2016 r. konflikt palestyńsko-izraelski zajął jedynie niewielką część jednego z pięciu głównych kierunków działań Unii Europejskiej w jej otoczeniu sąsiedzkim.

\section{Działania UE wobec konfliktu izraelsko-palestyńskiego w perspektywie nowych uwarunkowań wewnętrznych i międzynarodowych}

Wraz z dynamicznie zmieniającymi się uwarunkowaniami wewnętrznymi i międzynarodowymi, kontynuowanie dotychczasowej linii polityki Unii Europejskiej wobec konfliktu izraelsko-palestyńskiego staje się coraz mniej efektywne. Tendencję tę wyraźnie obnażyła operacja „Płynny Ołów” (2008/2009). Trzy dni po rozpoczęciu 
przez siły izraelskie tej operacji, 30 grudnia 2008 r. ministrowie spraw zagranicznych państw członkowskich UE, Wysoki Przedstawiciel ds. Wspólnej Polityki Zagranicznej i Bezpieczeństwa Javier Solana oraz Komisja Europejska we wspólnym oświadczeniu zaapelowali do Hamasu oraz rządu Izraela o natychmiastowe zaprzestanie działań zbrojnych i wznowienie rozmów pokojowych, uznając, iż tylko w ten sposób można zapewnić trwałe zakończenie konfliktu. Spójność Unii Europejskiej w praktyce pozostawiała jednakże wiele do życzenia. W dniach 4-6 stycznia 2009 r. na Bliski Wschód udały się trzy oddzielne unijne delegacje. Pierwsza, pod przewodnictwem francuskiego prezydenta Nicolasa Sarkozy’ego. Druga, reprezentująca unijną „,Trójkę”, w skład której weszli ministrowie spaw zagranicznych: Francji - Bernard Kouchner (przedstawiciel byłej prezydencji), Czech - Karl Schwarzenberg (przedstawiciel ówczesnej prezydencji) i Szwecji - Carl Bildt (przedstawiciel przyszłej prezydencji) oraz Komisarz ds. Stosunków Zewnętrznych i Polityki Sąsiedztwa - Benita Ferrero-Waldner. Trzecia, którą stanowił minister spraw zagranicznych Hiszpanii Miguel Moratinos. Wszystkie trzy delegacje miały ten sam cel - doprowadzić do zakończenia trwającego kryzysu w Strefie Gazy, niemniej fakt, że przybyły one w tym samym czasie wywoływał w stronach konfliktu dezorientację, która z nich tak naprawdę reprezentuje Unię Europejską. Możliwość skutecznego działania Unii Europejskiej osłabiał również fakt, że kryzys w Strefie Gazy toczył się w czasie, gdy w Unii Europejskiej zmieniała się prezydencja. O ile bowiem Francja pełniąca prezydencję w drugiej połowie 2008 r., znana ze swojej pro-palestyńskiej postawy, skłonna była do zdecydowanej reakcji przeciwko Izraelowi, to Czechy, które objęły prezydencję w dn. 1 stycznia 2009 r. zajęły w tym względzie znacznie bardziej umiarkowane stanowisko, które zostało poparte przez Niemcy, Włochy i Holandię (Tocci, 2009). Znaczącą porażką Unii Europejskiej w kryzysie w Strefie Gazy 2008/2009 był fakt, iż nie brała ona bezpośredniego udziału w mediacjach między Hamasem a Izraelem. Było to pokłosie nieuznawania przez Unię Europejską Hamasu i traktowania go, od 2003 r., jako ugrupowania terrorystycznego. Kiedy Hamas wygrał wybory w Autonomii Palestyńskiej w styczniu 2006 r. Unia Europejska nie uznała utworzonego przez to ugrupowanie rządu, a po rozłamie wśród Palestyńczyków przeszła do popierania Al. Fatahu. Nie uznając Hamasu i nie utrzymując kontaktów z jego przywódcami Unia Europejska straciła pozycję mediatora i tym samym znacznie ograniczyła swoje możliwości oddziaływania politycznego.

Przy kolejnych eskalacjach konfliktu na linii Izrael-Hamas $(2012 ; 2014)$ polityczna rola Unii Europejskiej i jej państw członkowskich była jeszcze mniejsza, a reakcje Unii można zobrazować znanym przysłowiem ,i wilk syty, i owca cała”. 19 listopada 2012 r. Rada Unii zaapelowała do stron konfliktu o zakończenie przemocy i uspokojenie sytuacji, potępiła ataki rakietowe na terytorium Izraela ze Strefy Gazy i uznała prawo tego państwa do obrony, zaznaczając jednocześnie, iż odpowiedź izraelska winna być proporcjonalna. Bardzo podobna w treści była deklaracja Rady Europejskiej w sprawie sytuacji w Strefie Gazy podczas izraelskiej operacji „Ochronny Brzeg”. Przyjęta 16 lipca 2014 r. deklaracja została zamieszczona w jednym dokumencie ze stanowiskiem Unii Europejskiej wobec kryzysu ukraińskiego, przy czym zajęła zdecydowanie mniej miejsca, co wyraźnie wskazywało na relatywnie malejące zaangażowanie Unii Europejskiej w rozwiązywanie konfliktu izraelsko-palestyńskiego w obliczu destabilizacji jej wschodniego sąsiedztwa. W przypadku obydwu operacji - „Filar 
Obrony” oraz „Ochronny Brzeg” Unia Europejska, konsekwentnie nie uznając Hamasu i nie utrzymując kontaktów z jego przywódcami nie odegrała żadnej roli mediacyjnej, popierając jedynie mediację egipską, podobnie jak kilka lat wcześniej w przypadku operacji „Płynny Ołów”. O ile jednak podczas operacji izraelskiej w Strefie Gazy 2008/2009 dużą rolę w wypracowaniu zawieszenia broni odegrał francuski prezydent Nicolas Sarkozy, wpływając na mediacje prowadzone przez Egipt, to w przypadku dwóch kolejnych eskalacji konfliktu (2012 i 2014), kiedy prezydentem był François Hollande, Francja nie odegrała już żadnej znaczącej roli (O’Donnell, 2016).

W obydwu przypadkach również, pomimo, iż obowiązywał traktat lizboński, który dawał Unii Europejskiej większe możliwości spójnego działania, różnice stanowisk państw unijnych takowe uniemożliwiły. Rozbieżne interesy państw członkowskich UE symbolizowało głosowanie nad przyznaniem Palestynie statusu nieczłonkowskiego państwa-obserwatora, na forum Zgromadzenia Ogólnego NZ, 29 listopada 2012 r. Pomimo, że Wysoka Przedstawiciel UE Catherine Ashton zadeklarowała przed głosowaniem, że Unia Europejska wielokrotnie wyrażała swoje poparcie dla Palestyny, by ta stała się członkiem ONZ, to głosowanie podzieliło unijne państwa członkowskie. Za poparciem wniosku Palestyńczyków zagłosowało 14 państw (Austria, Belgia, Dania, Cypr, Finlandia, Francja, Grecja, Hiszpania, Irlandia, Włochy, Luksemburg, Malta, Portugalia, Szwecja), jedno - Republika Czeska - opowiedziało się przeciwko, a 12 państw wstrzymało się od głosu (Bułgaria, Estonia, Łotwa, Litwa, Niemcy, Węgry, Holandia, Polska, Rumunia, Słowacja, Słowenia, Wielka Brytania).

Pomimo podziału pomiędzy unijnymi państwami członkowskimi względem tego głosowania Unia Europejska udziela znaczącego wsparcia Palestyńczykom zarówno, jeśli chodzi o budowanie i funkcjonowanie palestyńskich instytucji państwowych, jak również dla społeczeństwa palestyńskiego (Zając, 2011b). UE od wielu lat pozostaje największym donatorem pomocy finansowej dla Palestyny. Roczna, średnia pomoc finansowa dla Palestyńczyków ze strony UE i jej państw członkowskich wynosi miliard euro. Większość unijnej pomocy dla Autonomii Palestyńskiej jest obecnie przekazywana poprzez mechanizm PEGASE (Mécanisme Palestino-Européen de Gestion et d'Aide Socio-Economique) utworzony w 2008 r. Za jego pośrednictwem Unia Europejska wspomaga budowę palestyńskich instytucji państwowych oraz zapewniania doraźne potrzeby, takie jak wypłata emerytur, czy wynagrodzeń dla urzędników, co zapewnia utrzymanie podstawowych usług publicznych w Autonomii Palestyńskiej. Z funduszy PEGASE wypłacane są także świadczenia socjalne dla palestyńskich rodzin, żyjących w skrajnym ubóstwie, jak również wsparcie finansowe dla szpitali we Wschodniej Jerozolimie, udzielane od 2013 r. Pomoc w ramach PEGASE liczona jest w setkach milionów euro. Np. w 2015 r. wyniosła ona 178 mln euro ${ }^{2}$. Oddzielne fundusze unijne przekazywane są na pomoc uchodźcom palestyńskim w ramach wpłat do Agencji NZ do spraw Pomocy Uchodźcom Palestyńskim na Bliskim Wschodzie (UNRWA), której UE i jej państwa członkowskie są największym donatorem. W latach 2007-2014 wkład UE do UNRWA wyniósł ponad miliard euro.

Dążąc do zwiększenia efektywności pomocy udzielanej Palestyńczykom w 2017 r. UE przyjęła wspólną strategię dla Palestyny (EU Joint Strategy for Palestine). Głów-

${ }^{2}$ Dane ze strony Komisji Europejskiej: https://ec.europa.eu/neighbourhood-enlargement/neighbourhood/countries/palestine_en, 8.07.2017. 
nym jej założeniem jest skoordynowanie alokacji funduszy pomocowych przekazywanych Palestyńczykom przez 21 państw europejskich (Austrię, Belgię, Danię, Finlandię, Francję, RFN, Irlandię, Włochy, Litwę, Luksemburg, Holandię, Norwegię, Polskę, Rumunię, Słowenię, Słowację, Hiszpanię, Szwecję, Szwajcarię, Wielką Brytanię) oraz UE. Fundusze te mają wesprzeć implementację palestyńskiego Programu Polityki Narodowej (National Policy Agenda) na rzecz ekonomicznego i społecznego rozwoju Palestyny w latach 2017-2022. Koordynacja alokacji funduszy odbywać się będzie w pięciu filarach. Pierwsze dwa filary obejmują budowanie zdolności i wiarygodności instytucji państwa palestyńskiego. Filar trzeci i czwarty koncentrują się na działaniach usprawniających usługi dostarczane obywatelom oraz zapewnianie ich ochrony, zwłaszcza na terytoriach okupowanych. Piąty filar obejmuje działania wspierające rozwój gospodarczy Palestyny.

Wsparcie Unii Europejskiej w budowanie państwa palestyńskiego i dla Palestyńczyków, dotkniętych okupacją nie idzie w parze ze zdecydowanymi jej działaniami względem posunięć izraelskich. Wprawdzie w obliczu operacji „Płynny Ołów” Unia Europejska podjęła decyzję o zawieszeniu działań, prowadzonych na rzecz pogłębienia stosunków unijno-izraelskich, to jednak współpraca była kontynuowana między stronami w ramach układu stowarzyszeniowego, obowiązującego UE i Izrael od 2000 r., jak również Planu Działania przyjętego w 2005 r. w ramach Europejskiej Polityki Sąsiedztwa. W kilka tygodni po zakończeniu operacji „Płynny Ołów” relacje między obydwoma stronami toczyły się niezakłócone. W listopadzie 2009 r. UE i Izrael podpisały nowe porozumienie o współpracy rolnej, w lipcu 2012 r. obie strony przyjęły listę 60 konkretnych działań w 15 dziedzinach, mających służyć pogłębieniu wzajemnej współpracy. Izrael uczestniczy także w innych programach unijnych, takich jak: Erasmus Mundus, Twinning czy Horyzont 2020, co daje mu dodatkową możliwość korzystania z unijnych funduszy i grantów. Unia Europejska pozostaje także największym rynkiem zbytu dla Izraela; 1/3 izraelskich obrotów handlowych przypada właśnie na UE.

Wyraźną niekonsekwencję Unii Europejskiej w jej polityce wobec Izraela widać wobec kwestii osadnictwa izraelskiego na terytoriach okupowanych. Pomimo, że UE nie uznaje za integralną część terytorium Państwa Izrael ziem zajętych w wojnie sześciodniowej 1967 r., a osadnictwo izraelskie na tych ziemiach uznaje za nielegalne to jednak za deklaracjami nie idą stosowane działania. Przez wiele lat produkty wytwarzane przez firmy izraelskie na terytoriach okupowanych były znakowane jako produkty izraelskie, co oznaczało iż czerpały one z przywilejów, jakie płynęły z umów między Izraelem a UE. Dopiero w lipcu 2013 r. Komisja Europejska ogłosiła wytyczne w sprawie uprawnień podmiotów izraelskich i ich aktywności na terytoriach okupowanych przez Izrael od czerwca 1967 r., wykluczając możliwość korzystania przez nie z unijnych dotacji, instrumentów finansowych i nagród. W listopadzie 2015 r. Komisja Europejska przyjęła także wykładnię unijnych przepisów, zgodnie z którą produkty rolne, a także kosmetyki pochodzące $\mathrm{z}$ osiedli izraelskich na terytoriach okupowanych nie mogą być oznakowane jako produkty wyprodukowane w Izraelu. Etykiety na tychże produktach muszą wyraźnie wskazywać, że towary zostały wyprodukowane na terenie osiedli izraelskich. Wytyczne te są jednak różnie stosowane w poszczególnych państwach unijnych (Lovatt, 2016, s. 5). 
Obok rozbieżnych interesów i stanowisk państw unijnych w ostatniej dekadzie ujawniły się także wewnętrzne tarcia w Unii Europejskiej w odniesieniu do podziału kompetencji pomiędzy dotychczasowymi a nowo utworzonymi, na mocy traktatu lizbońskiego, instytucjami. HR/VP Catherine Ashton promowała koncepcję zniesienia specjalnych przedstawicieli Unii Europejskiej i przeniesienie ich obowiązków do ESDZ. W przypadku konfliktu izraelsko-palestyńskiego skutkowało to zawieszeniem, w styczniu 2014 r., funkcji Specjalnego Przedstawiciela UE ds. bliskowschodniego procesu pokojowego ${ }^{3}$. Pomysł ten był jednak mocno skrytykowany przez wielu dyplomatów, jako obniżający pozycję Unii Europejskiej na Bliskim Wschodzie. W rezultacie silnej krytyki, następczyni Ashton - Federica Mogherini powróciła do praktyki Specjalnych Przedstawicieli UE w regionach konfliktowych. W kwietniu 2015 r. na stanowisko Specjalnego Przedstawiciela UE ds. bliskowschodniego procesu pokojowego został mianowany włoski dyplomata Fernando Gentilini. Niemniej skuteczność jego działania jest utrudniona ze względu na malejącą $\mathrm{w}$ ostatnich latach pozycję polityczną Unii Europejskiej w rozwiązywaniu konfliktu izraelsko-palestyńskiego.

\section{Konkluzje}

„Kto nie idzie do przodu ten się cofa” - myśl ta wydaje się najlepszą konstatacją dla polityki Unii Europejskiej wobec konfliktu izraelsko-palestyńskiego w latach 20092017. W okresie tym Unia zasadniczo kontynuowała swoje dotychczasowe działania, tracąc jednak swoją siłę oddziaływania. Stosowanie dotychczasowych instrumentów przez Unię Europejską staje się bowiem niewystarczające w obliczu dynamicznie zmieniającej się sytuacji międzynarodowej.

Zapoczątkowana społecznymi ruchami w Tunezji w grudniu 2010 r. Arabska Wiosna rozlała się na inne państwa i w efekcie, po skumulowaniu się różnych czynników Bliski Wschód i Afryka stały się areną eskalujących konfliktów i kryzysów, na różnych poziomach i między różnymi aktorami. Na Bliskim Wschodzie zmienia się układ sił. Coraz wyraźniej widać narastającą rywalizację irańsko-saudyjską, która rzutuje na stosunki w całym regionie, a w grze bliskowschodniej coraz większą rolę odgrywają również Rosja i Turcja. Relatywna siła oddziaływania Unii Europejskiej w tym obszarze maleje. Również sceptyczny stosunek Trumpa do Unii Europejskiej osłabia pozycję Unii, a silniejszy zwrot administracji Trumpa w kierunku stanowiska proizraelskiego pogłębia różnice między USA a UE, co do wizji rozwiązania konfliktu izraelsko-palestyńskiego. Już w lutym 2017 r. Francja i Niemcy określiły stanowisko prezydenta Donalda Trumpa względem konfliktu izraelsko-palestyńskiego jako konfudujące i niepokojące.

Siła oddziaływania Unii Europejskiej maleje także wraz z jej rosnącymi problemami wewnętrznymi. Coraz bardziej widoczna rozbieżność stanowisk między

${ }^{3}$ Funkcja ta została utworzona w 1996 r. i od tego czasu była pełniona przez: Miguela Moratinosa (1996-2002), Marca Otte (2003-2011) oraz Andreasa Reinicke'a (2012-2013). Pomimo, że ich wpływ na proces pokojowy nie był duży, to jednak funkcja ta tworzyła Unii Europejskiej kanały oddziaływania politycznego i czyniła obecność UE w bliskowschodnim procesie pokojowym bardziej widoczną. 
unijnymi państwami członkowskimi rzutuje na politykę UE jako całości. Traktat lizboński daje wprawdzie Unii Europejskiej możliwości spójnego działania w zakresie wspólnej polityki zagranicznej, bezpieczeństwa i obrony jednak uzależnia je od woli politycznej państw członkowskich. W ostatnich latach polityka Unii Europejskiej w regionie Bliskiego Wschodu była determinowana przez trzy państwa: RFN, Francję i Wielką Brytanię. Proces Brexit, zakończony wyjściem Wielkiej Brytanii z UE osłabi siłę oddziaływania Unii na Bliskim Wschodzie. Unii Europejskiej dojdzie bowiem jeszcze jeden rywal w grze bliskowschodniej - Wielka Brytania, dla której Bliski Wschód jest tradycyjnie obszarem wpływu. Jeśli zatem Unia Europejska będzie chciała utrzymywać swoją pozycję w Afryce i na Bliskim Wschodzie, jedyną alternatywą może okazać się tworzenie UE dwóch prędkości, w której część unijnych członków zacieśni swoje relacje, pozostawiając inne kraje poza głównym rdzeniem.

\section{Bibliografia}

Council Conclusions on Gaza, 3199th Foreign Affairs Council meeting, Brussels, 19 November 2012, https://www.gov.uk/government/uploads/system/uploads/attachment_data/file/224288/evidence-eeas-council-conclusions-gaza-nov-2012.pdf, 4 lipca 2017.

Czachór Z. (2013), Kryzys i zaburzona dynamika Unii Europejskiej, Elipsa, Warszawa.

Danecki J., Sulowski S. (red.) (2011), Bliski Wschód coraz bliżej, Elipsa, Warszawa.

Declaration by the High Representative on behalf of the European Union on the Middle East Peace Process, Brussels, 29 November 2012, 16079/2/12 Rev 2 Presse 470.

EU divided in UN vote on Palestine's status (2012), „EurActiv”, 30 November.

EU renews its support to Palestinian Authority and Palestinian refugees with a first 2016 assistance package totalling €252.5 million, „Press Release”, European Commission, Brussels, 1 March 2016.

European Council conclusions on external relations (Ukraine and Gaza), European Council, Brussels, 16 July 2014.

European Joint Strategy of European Development Partners in Support of Palestine 2017-2020, https://eeas.europa.eu/sites/eeas/files/jp-palestine_brochure_en.pdf, 10 lipca 2017.

Fiedler R. (2010), Od przywództwa do hegemonii. Stany Zjednoczone wobec bliskowschodniego obszaru niestabilności w latach 1991-2009, Wydawnictwo Naukowe WNPiD UAM, Poznań.

France and Germany frown at Trump's Middle East policy (2017), „EurActiv”, 17 February.

General Assembly Votes Overwhelmingly to Accord Palestine 'Non-Member Observer State' Status in United Nations, 29 November 2012, https://www.un.org/press/en/2012/ga11317.doc.htm, 1 lipca 2017.

Grosse T. G. (red.) (2016), Polityki europejskie w dobie kryzysu, Scholar, Warszawa.

Guidelines on the eligibility of Israeli entities and their activities in the territories occupied by Israel since June 1967 for grants, prizes and financial instruments funded by the EU from 2014 onwards, „Official Journal of the European Union”, C 2005/9, 17.09.2013.

Human Rights in Palestine and Other Occupied Arab Territories, ,Report of the United Nations Fact-Finding Mission on the Gaza Conflict, General Assembly", A/HRC/12/48, 25 September 2009.

Interpretative Notice on indication of origin of goods from the territories occupied by Israel since June 1967, European Commission, C (2015) 7834 final, Brussels, 11.11.2015. 
Israel and European Union sign agricultural agreement, 4 November 2009, http://mfa.gov.i1/MFA/ PressRoom/2009/Pages/Israel_and_European_Union_sign_agricultural_agreement_4Nov-2009.aspx, 10 lipca 2017.

Koehler K. (2010), European Foreign Policy after Lisbon: Strengthening the EU as an International Actor, „Caucasian Review of International Affairs”, vol. 4 (1), Winter.

Koszel B. (2016), Problem uchodźców w Unii Europejskiej (2015-2016) w polityce Niemiec i Francji, „Stosunki Międzynarodowe - International Relations”, nr 3 (52).

Lovatt H. (2016), EU Differentiation and the Push for Peace in Israel-Palestine, „Policy Brief”, ECFR/194, October.

Lyon A., Mohammed A. (2011), Abbas stakes Palestinian claim to state at U.N., „Reuters”, 23 września.

Marczuk K. P. (2017), Kryzys uchodźczy 2014-2016 - podejścia Unii Europejskiej i Organizacji Narodów Zjednoczonych. Propozycje działań, „Krakowskie Studia Międzynarodowe”, nr 1.

Mickiewicz P. (2017), Przeciwdziałanie nielegalnej imigracji drogq morskq do UE. Źródła i potencjalne formy reakcji, „Krakowskie Studia Międzynarodowe”, nr 1.

Middle East Peace Process, 15.05.2016, https://eeas.europa.eu/headquarters.

O'Donnell H. (2016), The European Union as a Mediator in Israel-Palestine: Operations Cast Lead and Protective Edge, „EU Diplomacy Paper”, no. 1.

Osiewicz P. (2013), The Middle East Peace Process: Towards Another Stalmate, „Przegląd Politologiczny", no. 3.

Przybylska-Maszner B. (red.) (2011), The Arab Spring, Wydawnictwo Naukowe WNPiD UAM, Poznań.

Report of the United Nations High Commissioner for Human Rights on the implementation of Human Rights Council resolutions $S-9 / 1$ and $S-12 / 1$ Addendum Concerns related to adherence to international human rights and international humanitarian law in the context of the escalation between the State of Israel, the de facto authorities in Gaza and Palestinian armed groups in Gaza that occurred from 14 to 21 November 2012, A/HRC/22/35/Add.1, 6 March 2013, http://www.ohchr.org/Documents/HRBodies/HRCouncil/RegularSession/Session22/A. HRC.22.35. Add.1_AV.pdf, 1 lipca 2017.

Rothert A., Szymanek J., Zięba A. (red.) (2012), Zmiany polityczne w państwach arabskich. Wybrane zagadnienia ustrojowe, Elipsa, Warszawa.

Shared Vision, Common Action: A Stronger Europe: Shared Vision, Common Action: A Stronger Europe A Global Strategy for the European Union's Foreign And Security Policy, June 2016, http://eeas.europa.eu/archives/docs/top_stories/pdf/eugs_review_web.pdf, 4 lipca 2017.

Sicherman H. (1985), Europe's Role in the Middle East: Illusions and Realities, „Orbis”, vol. 28, no. 4, Winter.

Statebuilding for Peace in the Middle East: an EU Action Strategy. Joint Paper by EU High Representative Javier Solana and EU Commissioner for External Relations Benita Ferrero-Waldner, November 2007.

Statement by the European Union on the Situation in the Middle East, Paris, 30 décembre 2008, http://www.consilium.europa.eu/, 11 czerwca 2009.

Stolarczyk M. (2012), Implikacje kryzysu Unii Europejskiej dla dalszego procesu integracji europejskiej, „Krakowskie Studia Międzynarodowe”, nr 3.

Tereszkiewicz F. (2017), European Union Global Strategy from the Viewpoint of Eurosceptic Members of the European Parliament: Discursive Nodal Points, „International and Security Studies", no. 2 (wykorzystanie tekstu złożonego do druku za zgodą autora). 
Tocci N. (2009), Active but Acquiescent: The EU'S Response to the Israeli Military Offensive in the Gaza Strip, „Euro-Mediterranean Human Rights Network”, Brussels, May.

Tocci N. (2011), The EU, the Middle East Quartet and (In)effective Multilateralism, „Mercury. E-paper", no. 9, June.

Waśko-Owsiejczuk E. (2017), Wspótpraca polityczna i w zakresie bezpieczeństwa Stanów Zjednoczonych z Uniq Europejska po amerykańskich wyborach prezydenckich w 2016 r. - kontynuacja czy zmiana?, „Krakowskie Studia Międzynarodowe”, nr 1.

Węc J. (2012), Spór o ksztalt ustrojowy Wspólnot Europejskich i Unii Europejskiej w latach 19502010: między ideq ponadnarodowości a wspótpracq międzyrzqdowq: analiza politologiczna, Księgarnia Akademicka, Kraków.

Why Israel went to war in Gaza, „The Guardian”, 9 January 2009, https://www.theguardian.com/ world/2009/jan/04/israel-gaza-hamas-hidden-agenda, 30 czerwca 2017.

Zając J. (2010), Role Unii Europejskiej w regionie Afryki Pólnocnej i Bliskiego Wschodu, WUW, Warszawa, rozdz. IV.

Zając J. (2010), Środki i metody oddziatywania USA w bliskowschodnim procesie pokojowym (19912000), WUW, Warszawa.

Zając J. (2011a), Polityka zagraniczna i bezpieczeństwa jako determinanta modernizacji Unii Europejskiej, w: Modernizacja Unii Europejskiej-stan obecny i perspektywy, red. K. A. Wojtaszczyk, Wydawnictwo ASPRA, Warszawa.

Zając J. (2011b), Unia Europejska wobec idei państwa palestyńskiego, „Rocznik Integracji Europejskiej", no. 5.

Zając J. (red.) (2014), Unia Europejska w regionie śródziemnomorskim: między politykq wspólna a interesami państw członkowskich, WDiNP, Warszawa.

Zięba A. (2015), Ataki terrorystyczne w Unii Europejskiej w 2015 r., „Biuletyn”, Rządowe Centrum Bezpieczeństwa, nr 13, październik-grudzień.

Zięba R. (2011a), Przyszłość Unii Europejskiej jako projektu politycznego w świetle kryzysu 2008 roku, w: Kryzys 2008 roku a pozycja międzynarodowa Zachodu, red. R. Kuźniar, Scholar, Warszawa.

Zięba R. (2011b), Strategia bezpieczeństwa Unii Europejskiej w świetle Traktatu z Lizbony, w: Stabilizacja nieładu i destabilizacja ładu, Instytut Zachodni, Poznań, s. 18-23.

Zięba R. (2014), Traktatowe uwarunkowania polityki zagranicznej Unii Europejskiej: między polity$k q$ wspólnq a interesami państw członkowskich, w: Unia Europejska w regionie śródziemnomorskim: między polityka wspólnq a interesami państw członkowskich, red. J. Zając, WDiNP, Warszawa.

\section{Streszczenie}

W latach 2009-2017 Unia Europejska kontynuowała swoją dotychczasową politykę wobec konfliktu izraelsko-palestyńskiego, jednak w obliczu dynamicznie zmieniających się uwarunkowań wewnętrznych i międzynarodowych polityka ta staje się coraz mniej efektywna. Problemy, z jakimi Unia Europejska i jej państwa członkowskie borykają się od kilku lat - Brexit, destabilizacja obszaru Afryki Północnej i Bliskiego Wschodu, kryzys ukraiński, zmieniający się układ sił w świecie - to najważniejsze determinanty obecnej polityki UE wobec konfliktu izraelsko-palestyńskiego. W ich wyniku rola Unii Europejskiej w rozwiązywaniu konfliktu izraelsko-palestyńskiego, na tle innych aktorów, maleje.

Słowa kluczowe: Unia Europejska, konflikt izraelsko-palestyński, Palestyna, Izrael 
The European Union in the face of the Israeli-Palestinian conflict in 2009-2017

\section{Summary}

In 2009-2017, the European Union continued its prior policy toward the Israeli-Palestinian conflict. Nonetheless, taking into consideration the rapidly changing internal and international situation, this policy is becoming increasingly less effective. Problems confronting the European Union and its member states over the recent years, Brexit, the destabilization of North Africa and the Middle East, the Ukrainian crisis, the redistribution of power in the world system, to name a few - are the most significant determinants of the current EU policy towards the IsraeliPalestinian conflict. Compared to other actors, the role of the European Union in resolving the Israeli-Palestinian conflict has been decreasing.

Key words: European Union, Israeli-Palestinian conflict, Palestine, Israel 